\title{
The Electric Supply System of Berlin
}

$\mathrm{I}^{\mathrm{N}}$ a paper read to the Institution of Electrical Engineers on May 13, M. W. Davies gave an account of the electric supply system of Berlin and of recent changes and developments that have taken place in it.

Berlin is a rapidly growing eity. At the time of the Great War, it was still comparatively small, but was surrounded by a number of satellite towns each possessing its own electric supply system. In 1920 these towns were combined to form Greater Berlin, which is to-day more than half the size of Greater London, and has half its population. It covers an area of 300 square miles and has a population of more than four millions. The average density of the population is almost the same as that of London, but in Berlin the greater part of the population lives in flats, with the result that only 28 per cent of the total area is fully developed. The central district is bordered by lakes and woods covering a further 27 per cent. The remaining 45 per cent is mainly undeveloped country and small holdings. As a result of this concentration, the actual density of the population in central Berlin is very high.

In Great Britain a considerable part of the electric energy sold for domestic purposes is used for heating ; but in many parts of the Continent, owing to the extensive use of steam-heating, the development of an electrical heating load is very difficult. In winter, the temperature is often below zero. Most of the flats are equipped with steam central-heating, and so it is not easy to get a satisfactory market for electric cookers and water heaters. Mr. Davies made a special study of the Berlin Power and Light, Co.known in Germany as the 'Bewag'. He describes how the Company in 1924 attempted to solve the dis. tribution problem for this great industrial city by treating it as a single unit. In 1929 and during subsequent years, this method had to be modified in the light of experience.

The bulk of the electrical power in Berlin is supplied from two large central stations, Klingenberg on the east of the city and Kraftwerk West on the west. A large part of the power for the base load is imported over $100 \mathrm{kv}$. lines which bring power from two large stations on the lignite field in central Germany. These stations are relics of the War, and are gradually being extended. The only other station of importance is the one at Charlottenburg, which was reconditioned in 1929. It is fitted with pass-out turbines connected directly to a public steam-heating system. In addition, it has Ruths steam accumulators and so can deliver $73,000 \mathrm{k} . w . h$. per charge at a maximum rate of 50,000 k.v.a.

These steam accumulators are of great value in enabling the system to get over the peak load, which formerly caused some of the lines to be 'tripped' out of the supply. They can be put on to full load in a few seconds and so prevent a stoppage. A 25,000 k.w. steam accumulator is kept constantly on the lines, and furnishes part of the basic load. The average load of the whole system is very high, being $\mathbf{3 6} \cdot 2$ per cent of the maximum possible. The total consumption of electricity in Berlin is about 350 units per head of the population, which is larger than most other Continental cities.

For local government purposes, Berlin is divided into twenty districts, and sixteen of these are now supplied with electricity by the Bewag. The unification was not a sudden achievement, but was the result of careful planning. The movement started with the pooling of generating resources and was afterwards followed by that highly desirable result, the pooling of common tariffs.

\section{The Flax Industry in Great Britain}

\begin{abstract}
$\mathrm{A}^{\mathrm{N}}$
$\mathrm{N}$ interesting account of the history of flax production in Great Britain and the possible line of its development was given by Mr. G. O. Searle at the Annual Conference of the Textile Institute held in London on June 3-5. Though demands are increasing, the production of flax in Great Britain has fallen. In 1864 the total acreage in flax was 320,000 , but in 1930 only a tenth of this, since when it has been even lower and rather variable. With the exception of a few hundred acres in East Anglia, flax-growing remains a peasant industry centred in Northern Ireland. Careful selection and breeding has resulted in the production of varieties yielding nearly fifty per cent more fibre per acre than the older commercial seed.
\end{abstract}

The re-establishment of a flax industry in England depends on changing radically the sequence of processing operations and substituting mechanical methods for manual labour. A flax factory must do more than merely centralise the simple handeraft methods still largely used. Improved methods and new machinery must be developed for the four operations of handling, de-seeding, retting and scutching. Inasmuch as for the last three the flax is required in a thin layer, the expedient of sewing it into mats has been adopted, but this has not as yet been done in the process of harvesting. Such mats greatly simplify the handling of the fibres, and avoid the lifting, untying and re-tying of bundles as at present. The fibres remain in mats during the retting, drying and scutching, a machine for scutch. ing which will take the flax laterally as supplied continuously in the mat, having been developed. With these improvements in processing, the reestablishment of a flax industry in England on a permanent basis is possible.

Various aspects of the question of separating flax fibres from the plant stem were discussed at the Conference by Dr. W. H. Gibson, director of the Linen Industry Research Association. He emphasised the fact that, in the long run, the best results can be efficiently achieved only on the basis of a more profound knowledge of the character of the fibres, and of the tissues in which they are embedded, than 
is at present possessed. While much information as to the arrangement of the fibre within the stem has been obtained by microscopic examination, separation depends on the chemical nature of the tissues adjacent to the bundles.

Separation is usually effected by the biological process of retting, but this process is difficult to control and, with the present organisation of the industry in Northern Ireland whereby the grower himself carries out the retting, results in great irregularity in the quality of the flax. A mechanical flax-breaker has just been developed, effectively loosening the ring of fibre bundles from the wood, which may then be knocked out in scutching. If this operation could be carried out by the growers, the partially separated but unretted fibres could be transported cheaply to the flax spinners, who could then treat the fibres so as to obtain a more uniform product.

Chemical retting has been much investigated of recent years and lends itself to proper control. The fibre obtained differs somewhat from biologically retted material, being denser and lighter in colour. At present, mechanical difficulties of handling the flax in the various operations have prevented the large-scale development of chemical retting processes.

By treating the fibres so that they break up into their ultimate fibre strands, flax may be spun on cotton machinery and incorporated in mixed yarns. This 'cottonisation' process may provide an outlet for low-quality flax grown for linseed, and make possible the utilisation of waste flax for the manu. facture of high-grade paper.

\section{Fishery Research in the Eastern Mediterranean*}

$\mathrm{T}$ EE eastern basin of the Mediterranean still offers almost a virgin field for the marine biologists. Apart from such occasional visits as those of the German Pola and the Danish Thor Expeditions, the main source of information now comes from the Fisheries Research Directorate of Egypt. This Directorate, founded originally as a Fisheries Research Office in 1919 under the direction of Mr. G. W. Paget, has passed through various vicissitudes; but it should now be sufficiently established to prove its value. As in most such undertakings, work of this nature starts from small beginnings. The foundations were well laid by Mr. Paget in his broad surveys of the lake and sea fisheries and his careful study of the sponge grounds; and by his inauguration of a system for the collection of necessary statistics. Special attention was then also paid to the growth and culture of the grey mullets which make up so large a proportion of the catches from the Delta lakes.

Owing to political upheavals, fisheries research lapsed for the period 1924-27. After that time, the office was once more opened under the direction of Mr. R. S. Wimpenny. Research was further developed under his regime, and two important additions were made to the facilities for investigation. A special research vessel, designed on the lines of a modern large steam trawler, H.E.M.S. Mabahiss, was completed by Messrs. Swan, Hunter, and Wigham Richardson, and a research laboratory was built near Fort Kait Bey on the eastern harbour of Alexandria. Interesting experiments were also carried out on the transport by air of grey mullet fry to the inland lake Qarûn, which appears to have been successfully stocked. On Mr. Wimpenny's departure at the end of 1931 , the direction was taken over by Dr. Hussein Faouzi.

In 1932 the Mabahiss was lent by the Egyptian Government for the Sir John Murray Expedition to the Indian Ocean under the leadership of Lieut.-

* Rapport sur les Pêcheries d'Egypte en 1932. Par Ibrahim AbdEl-Galil Abou-Samara. Direction des Recherches des Pêcheries. Administration des Gardes-Côtes et des Pêcheries. Ministère des
Finances. Le Caire, Imprimeries Nationale, Boulac 1935 .

inances. Le Caire, Imprimeries Nationale, Boulac 1935 . The Fishery Grounds Near Alexandria. (1) Preliminary Report. By Adolf Steuer. Ibid. Notes and Memoirs No. 8, 1935. (2) A Bottom Sample taken at Alexandria. By Aristocle Vatova. No. 9 (3) Cirripeds. By Hjalmar Broch. No. 10. (4) Some Marine Mites from Alexandria. 12 .
Colonel R. B. Seymour Sewell, and Dr. Faouzi also accompanied the expedition. The experience thus gained should prove of great value to the Directorate, and it is gratifying to see that research is being advanced in another direction by facilities offered to visiting research workers at the Fisheries Laboratory. A distinguished visitor in 1933 was Prof. Adolf Steuer, co-director of the Italo-German Institute of Marine Biology at Rovigno d'Istria, and results of his work and that of a number of specialists are now appearing in the "Notes and Memoirs" published by the Directorate.

The preliminary report on the fishery grounds near Alexandria contains interesting observations on the seasonal sequence of the plankton. There is a big outburst of phytoplankton in September and October which appears to be determined by the Nile flood, and the influence of this water extends over a large area. It has recently been shown by Liebman ${ }^{1}$ to affect even the waters of the Palestine coasts, where the planktonic sequence is similar to that at Alexandria. Such observations should have important bearings on the movements of sardines and other fish. A further noteworthy feature is the occurrence of the green algæ, Caulerpa and Halimeda, down to the fifty fathom line off the Egyptian coast, an index of the excessive transparency of the water.

Another activity of the Fisheries Directorate is the attempt to restock with fish the springs of the Siwa oasis. This is an experiment that will necessarily require careful watching. Preliminary observations have shown that the bolti (Tilapia) which are being used do not feed on the cyprinodonts reared to feed on mosquito larvæ, but do feed on the latter. It is to be hoped that they do not change their habit and repeat the effects of the previous introduction of an ill-judged species which devoured the cyprinodonts so carefully inserted by the Department of Hygiene.

Now that research is on so sound a footing, the Egyptian Government should see grounds for fostering and furthering investigations in this most in. teresting region. There can be no doubt that knowledge so gained will prove of immense value in predicting and controlling the extent of the fisheries.

\section{F. S. RUSSELL.} 1Oceanographic Observations on the Palestine Coasts. By E.
Liebman. Comm. Int. Explor. Sci. Mediterr., Rapp. Proc. Verb., 1935. 